\title{
Characteristics of atmospheric mercury deposition and size-fractionated particulate mercury in urban Nanjing, China
}

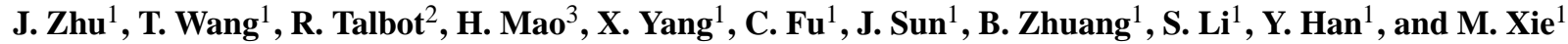 \\ ${ }^{1}$ School of Atmospheric Sciences, Nanjing University, Nanjing 210093, China \\ ${ }^{2}$ Department of Earth \& Atmospheric Sciences, University of Houston, Houston, TX 77204, USA \\ ${ }^{3}$ Department of Chemistry, State University of New York, College of Environmental Science and Forestry, Syracuse, \\ NY 13219, USA
}

Correspondence to: T. Wang (tjwang@ @ju.edu.cn)

Received: 13 July 2013 - Published in Atmos. Chem. Phys. Discuss.: 1 November 2013

Revised: 25 January 2014 - Accepted: 29 January 2014 - Published: 3 March 2014

\begin{abstract}
A comprehensive measurement study of mercury wet deposition and size-fractionated particulate mercury $\left(\mathrm{Hg}^{\mathrm{P}}\right)$ concurrent with meteorological variables was conducted from June 2011 to February 2012 to evaluate the characteristics of mercury deposition and particulate mercury in urban Nanjing, China. The volume-weighted mean (VWM) concentration of mercury in rainwater was $52.9 \mathrm{ng} \mathrm{L}^{-1}$ with a range of $46.3-63.6 \mathrm{ng} \mathrm{L}^{-1}$. The wet deposition per unit area was averaged $56.5 \mu \mathrm{g} \mathrm{m}^{-2}$ over 9 months, which was lower than that in most Chinese cities, but much higher than annual deposition in urban North America and Japan. The wet deposition flux exhibited obvious seasonal variation strongly linked with the amount of precipitation. Wet deposition in summer contributed more than $80 \%$ to the total amount. A part of contribution to wet deposition of mercury from anthropogenic sources was evidenced by the association between wet deposition and sulfates, as well as nitrates in rainwater. The ions correlated most significantly with mercury were formate, calcium, and potassium, which suggested that natural sources including vegetation and resuspended soil should be considered as an important factor to affect the wet deposition of mercury in Nanjing. The average $\mathrm{Hg}^{\mathrm{P}}$ concentration was $1.10 \pm 0.57 \mathrm{ng} \mathrm{m}^{-3}$. A distinct seasonal distribution of $\mathrm{Hg}^{\mathrm{P}}$ concentrations was found to be higher in winter as a result of an increase in the $\mathrm{PM}_{10}$ concentration. Overall, more than half of the $\mathrm{Hg}^{\mathrm{P}}$ existed in the particle size range less than $2.1 \mu \mathrm{m}$. The highest concentration of $\mathrm{Hg}^{\mathrm{P}}$ in coarse particles was observed in summer, while $\mathrm{Hg}^{\mathrm{P}}$ in fine particles dominated in fall and winter. The size distribution of averaged mercury content in particulates was bimodal, with
\end{abstract}

two peaks in the bins of $<0.7 \mu \mathrm{m}$ and 4.7-5.8 $\mu \mathrm{m}$. Dry deposition per unit area of $\mathrm{Hg}^{\mathrm{P}}$ was estimated to be $47.2 \mu \mathrm{g} \mathrm{m}^{-2}$ using meteorological conditions and a size-resolved particle dry deposition model. This was $16.5 \%$ less than mercury wet deposition. Compared to $\mathrm{Hg}^{\mathrm{P}}$ in fine particles, $\mathrm{Hg}^{\mathrm{P}}$ in coarse particles contributed more to the total dry deposition due to higher deposition velocities. Negative correlation between precipitation and the $\mathrm{Hg}^{\mathrm{P}}$ concentration reflected the effect of scavenging of $\mathrm{Hg}^{\mathrm{P}}$ by precipitation.

\section{Introduction}

Mercury ( $\mathrm{Hg}$ ) is a toxic global pollutant that can have serious negative effects on human health and the ecosystem via bioaccumulation and biomagnification of methylated mercury through the food chain in aquatic systems (Lindqvist, 1991; Schroeder and Munthe, 1998). Atmospheric mercury exists in three forms due to different chemical and physical property: gaseous elemental mercury (GEM), reactive gaseous species (RGM) and particulate mercury $\left(\mathrm{Hg}^{\mathrm{P}}\right)$. GEM, the predominant form $(>95 \%)$, is very stable in the atmosphere with a lifetime of 0.5-2 yr (Schroeder and Munthe, 1998). In contrast, since RGM and $\mathrm{Hg}^{\mathrm{P}}$ have significantly higher reactivity, deposition velocities, and water solubility than GEM, deposition of atmospheric mercury is largely dominated by RGM and $\mathrm{Hg}^{\mathrm{P}}$ (Fu et al., 2010a; Ahn et al., 2011; Sakata and Asakura, 2007; Zhang et al., 2009). Atmospheric deposition is widely recognized as the only process for scavenging of atmospheric mercury and an 
important source of mercury to terrestrial and aquatic ecosystems (Lindberg et al., 1998; Miller et al., 2005; Selvendiran et al., 2008; Landis et al., 2002, Rolfhus et al., 2003).

Atmospheric mercury deposition includes both wet and dry processes, and each has their own characteristics (Sanei et al., 2010). The relative importance of the wet and dry deposition pathways varies considerably depending upon location, climate, and anthropogenic sources (Rea et al., 1996; Sakata and Marumoto, 2005; Miller et al., 2005). Monitoring of the deposition flux and understanding the characteristics of mercury deposition are required for assessment of the environmental risks of mercury. In North America, more than 100 Mercury Deposition Network (MDN) sites are collecting data to examine long-term trends in mercury deposition at regional scales (Vanarsdale et al., 2005; Lai et al., 2007; Hall et al., 2005; Prestbo and Gay, 2009). The European Monitoring and Evaluation Programme (EMEP) suggested that the typical concentrations of total mercury in rainwater and wet deposition flux were quite different across Europe (Wangberg et al., 2007; Yang et al., 2009; Ebinghaus et al., 1999). China has been regarded as one of the largest atmospheric mercury emission sources globally (Streets et al., 2005; Wu et al., 2006). However, limited monitoring sites and data are available to understand mercury deposition in China. Measurements of mercury deposition in China have been conducted in remote areas like Mt. Changbai (Wan et al., 2009b) in northeastern China, as well as Mt. Fanjing (Xiao et al., 1998), Mt. Leigong (Fu et al., 2010a), Wujiang River basin (Guo et al., 2008), and Mt. Gongga (Fu et al., 2008, 2010b) in southwestern China. The few measurements of mercury deposition in the urban area of Guiyang (Feng et al., 2002; Tan et al., 2000) and Changchun (Fang et al., 2001, 2004) suggested much more serious mercury contamination than that in remote areas and most other countries. Obviously there are still limitations to fully describing temporal and spatial distributions of mercury deposition in China and its relationship to global atmospheric mercury cycling. Long-term continuous measurements of atmospheric mercury in China, especially in urban areas, are greatly needed.

Particulate mercury $\left(\mathrm{Hg}^{\mathrm{P}}\right)$ is one of the major forms of mercury lost via wet and dry deposition (Sakata and Marumoto, 2002). Particulate mercury is associated with airborne particles, such as dust, soot, and sea salt aerosols, and is likely produced by adsorption of RGM onto atmospheric particles (Lu and Schroeder, 2004). Most research indicates higher $\mathrm{Hg}^{\mathrm{P}}$ concentrations and fractions in suspended particles in urban or industrial areas than in rural areas (Fang et al., 2001a, 2011a, 2012; Kim et al., 2012). Also, some measurements of $\mathrm{Hg}^{\mathrm{P}}$ were conducted to estimate the dry deposition of mercury onto the particle surface (Fang et al., 2011b, 2011c; Wan et al., 2009b; Keeler et al., 1995; Chand et al., 2008). The deposition rate of $\mathrm{Hg}^{\mathrm{P}}$ depends on the particle diameter, especially for dry deposition (Lestari et al., 2003; Peters and Eiden, 1992). Particle diameter plays a key role since it affects gravitational settling, aerodynamic re- sistance, and surface resistance (Zhang et al., 2001). Xiu et al. (2005) and Wang et al. (2006) studied $\mathrm{Hg}^{\mathrm{P}}$ in two major cities in China, Shanghai and Beijing, with four and five size cut stages, respectively. A small number of size cut stages does not reveal a detailed analysis of the full size distribution of $\mathrm{Hg}^{\mathrm{P}}$. Ten size fractions of $\mathrm{Hg}^{\mathrm{P}}$ were collected by Feddersen et al. (2012) and Kim et al. (2012) to evaluate the dominant fractions and variability of $\mathrm{Hg}^{\mathrm{P}}$ in North America and Korea, respectively. The size distribution of $\mathrm{Hg}^{\mathrm{P}}$ changes due to physical and chemical processes including adsorption, nucleation, and other gas-particle partitioning mechanisms, ambient particle concentrations, and meteorological conditions (Kim et al., 2012). To better understand the fate and transport of $\mathrm{Hg}^{\mathrm{P}}$, more seasonal variations in size-segregated $\mathrm{Hg}^{\mathrm{P}}$ concentrations need to be determined.

Nanjing, the capital of Jiangsu Province, is located in the northwest of the Yangtze River delta (YRD) region and more than $200 \mathrm{~km}$ west to China Sea, which is one of the most industrialized and urbanized regions in China and is potentially affected by marine conditions. Nanjing is the second largest city in eastern China, with a high population density and large energy consumption. Due to rapid economic development, environmental pollution has become a problem of increasing concern in Nanjing. The containment of atmospheric mercury is one of the most serious environmental problems. As reported in Zhu et al. (2012), the 2011 annual average concentration of total gaseous mercury (TGM) was $7.9 \pm 7.0 \mathrm{ng} \mathrm{m}^{-3}$, significantly higher than the Northern Hemisphere background value $\left(\sim 1.5 \mathrm{ng} \mathrm{m}^{-3}\right)$. However, the level of atmospheric mercury deposition in Nanjing and the YRD region has not been determined until now. In this study, the mercury content in precipitation and atmospheric particles in nine size fractions from $<0.4$ to $10 \mu \mathrm{m}$ were monitored from June 2011 to February 2012 in urban Nanjing. To the best of our knowledge, this is the first comprehensive study of atmospheric mercury deposition and $\mathrm{Hg}^{\mathrm{P}}$ in the YRD urban region.

\section{Experimental method}

\subsection{Sampling site and methods}

Deposition of atmospheric mercury and $\mathrm{Hg}^{\mathrm{P}}$ was monitored on the top of a 24-storied building $(75 \mathrm{~m})$ on the Gulou campus of Nanjing University. Our site $\left(32.05^{\circ} \mathrm{N}\right.$, $118.78^{\circ} \mathrm{E}$ ) is located in the heart of the urban area of Nanjing. The climate and land covers in Nanjing and a detailed description of our site can be found in Zhu et al. (2012). The samples of mercury in this study were collected from June 2011 to February 2012, representing summer, fall, and winter. Samples in spring 2012 were contaminated due to sample handling, so the characteristics in spring cannot be used in this study. Simultaneously, total gaseous mercury (TGM) and meteorological parameters including wind, 
temperature, precipitation, relative humidity, and solar radiation were measured with the same method described in Zhu et al. (2012).

Wet deposition samples were collected using an automated precipitation sampler. The sampler opened automatically when rain was detected. Otherwise, the collection bottle was sealed to protect $\mathrm{Hg}^{\mathrm{P}}$ from depositing. Normally, Teflon sample collection bottles (volume: $100 \mathrm{~mL}$ ) were manually replaced with an acid-cleaned new one every 5 days if it rained. In total, 22 samples, all of which were more than $50 \mathrm{~mL}$, were collected during the study period. The samples were preserved at around $4{ }^{\circ} \mathrm{C}$ in a refrigerator, adding trace-metal-grade $\mathrm{HCl}$ before analysis. The total mercury concentration was determined in the Modern Analysis Center of Nanjing University using a cold vapor atomic fluorescence spectrometer (CVAFS) following US EPA method 1631 (US EPA, 2002). The average method detection limit is $0.08 \mathrm{ng} \mathrm{L}^{-1}$, and the relative standard deviation (RSD) $\leq 2 \%$. Blank was determined by rinsing the whole sampling system with ultrapure water. The blank was obviously under the detection limits in all cases. Simultaneously, another bottle of precipitation sample was used for analyzing major water-soluble ions in precipitation, $\mathrm{NH}_{4}^{+}, \mathrm{Ca}^{2+}, \mathrm{Mg}^{2+}$, $\mathrm{Na}^{+}, \mathrm{K}^{+}, \mathrm{Cl}^{-}, \mathrm{NO}_{3}^{-}, \mathrm{SO}_{4}^{2-}, \mathrm{F}^{-}$, oxalate, and formate using a Metrohm 850 professional IC.

An Andersen eight-stage cascade impactor was used to collect size-segregated particles with cut-off sizes of 10-9, $\sim 5.8, \sim 4.7, \sim 3.3, \sim 2.1, \sim 1.1, \sim 0.7$, and $\sim 0.4 \mu \mathrm{m}$. The sampler was operated at a flow rate of $28.3 \mathrm{~L} \mathrm{~min}^{-1}$ to maintain maximum efficiency, and the air pump was calibrated before sampling. Sample campaigns were conducted semimonthly on random days. Generally sample collection began at noon and continued for 3 days. Each filter was conditioned in a desiccator for more than $24 \mathrm{~h}$ and weighed by an electronic balance three times with a precision of $0.01 \mathrm{mg}$ before and after collection. Prior to analysis, the sampled filters were soaked in $10 \mathrm{~mL}$ doubling diluted aqua regia solution separately and extracted using ultrasonication for $30 \mathrm{~min}$, followed by digestion with a microwave digestion system for $2 \mathrm{~h}$ to ensure that total mercury was dissolved. Then the extracted samples were analyzed using a cold vapor atomic fluorescence spectrometer (CVAFS) following EPA method 1631E (US EPA, 2002) after being set aside to cool for $1 \mathrm{~h}$, and ultrapure water was added to keep a constant volume of $25 \mathrm{~mL}$.

\subsection{Calculation of wet and dry deposition}

Wet deposition flux is calculated by multiplying the measured total concentration of mercury concentration in rainwater ( $\mathrm{THg}$ ) by the corresponding precipitation amount (Prec), as shown in Eq. (1):

$F_{\mathrm{w}}=\mathrm{THg} \times$ Prec,

where $F_{\mathrm{w}}$ represents wet deposition flux of mercury.
Dry deposition flux is calculated as the product of the sum of the size-fractionated concentration of $\mathrm{Hg}^{\mathrm{P}}$ and its respective dry deposition velocity as shown in Eq. (2):

$F_{\mathrm{d}}=\sum C_{\mathrm{HgP}} \times V_{\mathrm{d}}$,

where $F_{\mathrm{d}}$ is dry deposition flux of $\mathrm{Hg}^{\mathrm{P}}, C_{\mathrm{HgP}}$ is the concentration of $\mathrm{Hg}^{\mathrm{P}}$ in each size fraction, and $V_{\mathrm{d}}$ is the corresponding dry deposition velocity.

A size-resolved particle dry deposition model developed by Zhang et al. (2001) is used to estimate dry deposition velocity for each size fraction. The model uses the same method as that used by Slinn (1982) for modeling particle dry deposition, but with a simplified empirical parameterization for all deposition processes. This parameterization calculates particle dry deposition velocity as a function of particle size and meteorological variables that are measured at our site. It includes deposition processes, such as turbulent transfer, Brownian diffusion, impaction, interception, gravitational settling, and particle rebound. Our estimation of deposition flux should be more accurate than those using a constant deposition velocity in previous studies such as Fang et al. (2012), Wang et al. (2006), and Lombard et al. (2011).

\section{Results and discussion}

\subsection{Concentration of mercury in precipitation and wet deposition}

From June 2011 to February 2012, 22 samples of rainwater were collected at our site. The total mercury ( $\mathrm{THg}$ ) concentration in precipitation as well as daily and 5-day accumulated precipitation amount and the calculated THg deposition flux are displayed in Fig. 1. The maximum THg concentration was $63.6 \mathrm{ng} \mathrm{L}^{-1}$, occurring during 1-5 June 2011, and the minimum was $46.3 \mathrm{ng} \mathrm{L}^{-1}$ sampled during 16-20 October 2011. However, the 5-day accumulated maximum $\left(11.6 \mu \mathrm{g} \mathrm{m}^{-2}\right)$ mercury wet deposition was collected during 16-20 July 2011, which constituted almost $20 \%$ of the total wet deposition of 9 months. Similarly, both Keeler et al. (2005) and Lombard et al. (2011) reported a single rainfall event contributing approximately 17 and $14 \%$, respectively, to the annual wet deposition in North America. Table 1 provides a summary of all data during our study period. The volume-weighted mean (VWM) concentration of mercury of all samples was $52.9 \mathrm{ng} \mathrm{L}^{-1}$, with a precipitation depth of $1067.7 \mathrm{~mm}$. The mercury wet deposition calculated as the product of the concentration and amount of precipitation was $56.5 \mu \mathrm{g} \mathrm{m}^{-2}$ over 9 months.

Our study period of 9 months represent the seasons of summer (June-July-August in 2011), fall (SeptemberOctober-November in 2011) and winter (December in 2011 and January, February in 2012), respectively. Seasonal variation of mercury wet deposition is apparent in Table 1. Deposition in summer accounted for a substantial portion of the 


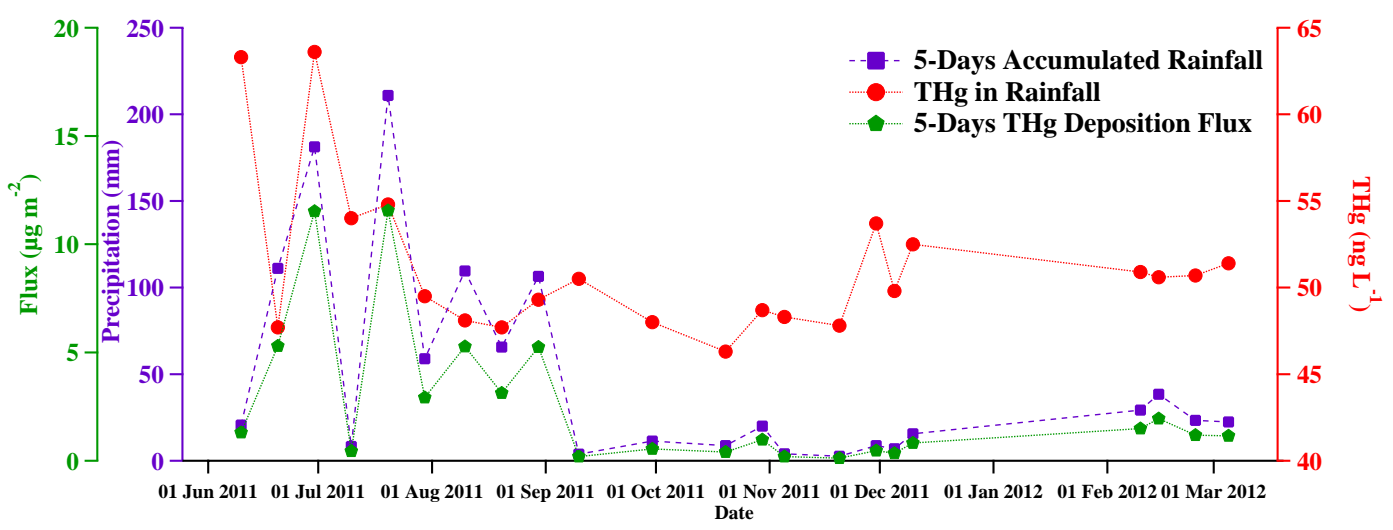

Fig. 1. Time series of mercury concentration in precipitation, wet deposition flux, and precipitation.

Table 1. The statistical summary of mercury concentration, precipitation, and wet deposition flux.

\begin{tabular}{lrrr}
\hline & $\begin{array}{r}\text { VWM concentration } \\
\left(\mathrm{ng} \mathrm{L}^{-1}\right)\end{array}$ & $\begin{array}{r}\text { Precipitation amount } \\
(\mathrm{mm})\end{array}$ & $\begin{array}{r}\text { Wet deposition flux } \\
\left(\mu \mathrm{g} \mathrm{m}^{-2}\right)\end{array}$ \\
\hline Summer & 53.5 & 872.6 & 46.7 \\
Fall & 49.0 & 59.2 & 2.9 \\
Winter & 51.0 & 135.9 & 6.9 \\
All data & 52.9 & 1067.7 & 56.5 \\
\hline
\end{tabular}

total deposition, which contributed more than $80 \%$, with the highest monthly deposition flux of $18.1 \mu \mathrm{g} \mathrm{m}^{-2}$ month $^{-1}$ in June. Correspondingly, the greatest VWM concentration of mercury in precipitation $\left(53.5 \mathrm{ng} \mathrm{L}^{-1}\right)$ was also measured in summer. However, seasonal differences in the VWM concentration were not as significant as those in deposition flux. The correlation coefficient $(r)$ between the VWM concentration and deposition flux was 0.41 compared with 0.99 between precipitation amount and deposition flux. As a result, the seasonal variability in mercury wet deposition was less consistent with that in VWM concentrations, while it was more strongly linked to that in precipitation amounts. Compared to other seasons, the combination of higher relative concentrations and more precipitation in summer enhanced the overall flux. Similar seasonal patterns were observed in both deposition flux and concentration in remote areas of China (Fu et al., 2010a, b) and North America (Choi et al., 2008; Mason et al., 2000; Keeler et al., 2005; Sanei et al., 2010; Lombard et al., 2011), with the annual maximum in summer. It was suggested by Keeler et al. (2005) and Mason et al. (2000) that this annual maximum was mainly due to more effective scavenging by rain in summer than by snow in the cold season. Mercury is not incorporated into cold cloud precipitation as efficiently as in warm cloud precipitation (Landis et al., 2002). However, snow hardly occurred in Nanjing during the 2012 winter. The relationship between precipitation and deposition flux suggests that there is a continual source of mercury during a precipitation event. This source is likely the oxidation of GEM via gas-phase and/or in-cloud aque- ous reactions (Mason et al., 2000). Enhanced photochemical activities in summer can probably enhance the rate of GEM oxidation (Munthe et al., 1995). Also, as hypothesized by Zhu et al. (2012), mercury released from mercurycontaminated soils during the warm season may have caused very high TGM peaks in Nanjing; this may be one of the important sources for mercury wet deposition in summer. On the other hand, a positive correlation between $\mathrm{THg}$ concentrations and precipitation amounts $(r=0.32)$ indicates that RGM and $\mathrm{Hg}^{\mathrm{P}}$ may not be scavenged effectively and completely by precipitation from the atmosphere or continuous emission sources in Nanjing.

\subsection{Comparison with other sites}

A comparison of $\mathrm{THg}$ concentrations in precipitation and wet deposition flux between our site in Nanjing and other sites around the world is given in Table 2. Differences among the data at these sites were very distinct. Overall, THg concentrations and wet deposition flux at urban sites were both higher than those at rural sites, which is in line with the point demonstrated by Fang et al. (2004) and Landis et al. (2002) that human activities in urban areas can enhance mercury concentrations in precipitation. $\mathrm{THg}$ concentrations in rural China were comparable to most literature data from rural sites in North America, Europe, and northeastern Asia. However, THg levels in urban China were much higher than those in urban North America, and even urban Japan, which is close to China. Since measurements of mercury deposition 
in urban China are very limited, the data at our site can be compared only with those from Guiyang and Changchun in China. Table 2 shows that wet deposition of mercury in urban Nanjing was much lower than that in Guiyang and Changchun. Coal burning is one of the most important sources of atmospheric mercury, and more coal burning occurs in these two cities than in Nanjing. This difference was enhanced in winter, when space heating was practiced, in Guiyang and Changchun, but not in Nanjing. Moreover, the measurements in Guiyang and Changchun were conducted 10 years earlier than this study. During the past 10 years, the mercury content in coal decreased notably because the Chinese government enacted a series of policies to control mercury emissions from major coal-fired industrial sources.

In comparison, the wet deposition during the 9 months $\left(56.5 \mu \mathrm{g} \mathrm{m}^{-2}\right)$ in Nanjing was 3-8 times higher than the value in Japanese and North American urban sites, resulting from higher VWM concentrations in Nanjing $\left(52.9 \mathrm{ng} \mathrm{L}^{-1}\right)$ than the values (3.2-25.9 $\mathrm{ng} \mathrm{L}^{-1}$ ) at MDN sites (National Atmospheric Deposition Program, 2012). London, an industrial megacity, showed comparable $\mathrm{THg}$ concentrations and deposition flux (Yang et al., 2009).

\subsection{Association between mercury and major ions in precipitation}

Major water-soluble ions including $\mathrm{H}^{+}, \mathrm{F}^{-}, \mathrm{Cl}^{-}, \mathrm{NO}_{3}^{-}$, $\mathrm{SO}_{4}^{2-}, \mathrm{Na}^{+}, \mathrm{NH}_{4}^{+}, \mathrm{K}^{+}, \mathrm{Ca}^{2+}, \mathrm{Mg}^{2+}$, formate, and oxalate in each precipitation sample were analyzed during our study period. Among the ionic constituents, sulfate contributed the largest amount $(39.31 \%)$, followed by magnesium $(19.16 \%)$, nitrate $(16.04 \%)$, and ammonium $(6.48 \%)$. The ionic balance of rainwater samples demonstrated a trend as $\mathrm{SO}_{4}^{2-}>\mathrm{NO}_{3}^{-}>\mathrm{Cl}^{-}>\mathrm{C}_{2} \mathrm{O}_{4}^{2-}>\mathrm{HCOO}^{-}$for anions and $\mathrm{Mg}^{2+}>\mathrm{NH}_{4}^{+}>\mathrm{Na}^{+}>\mathrm{K}^{+}>\mathrm{Ca}^{2+}$ for cations. The total anions and cations contributed $68 \%$ and $32 \%$ to the rainwater composition, respectively. The $\mathrm{pH}$ value of rainwater ranged from 4.62 to 6.58 , with an average of 5.86 due to the dominant contribution from sulfate and nitrate. Table 3 shows correlation coefficients between deposition fluxes of the ions of interest. Better correlations indicate common sources of various ions, and hence association between ions is a useful indicator of their potential sources in rain water.

Sodium and chloride, elements associated with sea water, were highly correlated $(r=0.98, p<0.01)$. The average $\mathrm{Cl} / \mathrm{Na}$ mole ratio was 1.18 in our study, near the ratio of 1.16 in seawater (Seinfeld and Pandis, 2006; Caffrey et al., 2010); thus sodium and chloride in rainwater in Nanjing came from sea salt aerosols. However, mercury did not correlate well with sodium and chloride $(r=0.37$ and 0.23 , respectively, with poor significance $p>0.05$ ). Little contribution to mercury deposition from sea salt aerosols was suggested although Nanjing is often under the influence from marine condition. This was possibly caused by continental emission sources entrained in marine air masses en route to
Nanjing that dominated over the marine air chemical composition and interfered with the correlation between mercury deposition and sea salt.

Sulfates and nitrates made the largest contribution to the anions in rainwater and comprised more than $50 \%$ of the total mass. Paired depositions and concentrations of sulfates and nitrates both showed a strong correlation $(r=0.95$ and $r=0.90$, respectively). The high correlation coefficients indicated their origin from same regions of their precursors $\mathrm{SO}_{2}$ and $\mathrm{NO}_{\mathrm{X}}$, which are mainly emitted by anthropogenic sources such as fossil fuel combustion and other high temperature processes. As previously mentioned, coal combustion is one of the most important anthropogenic sources of mercury. However, the correlation coefficient between mercury and sulfate was 0.39 and that is 0.44 between mercury and nitrate, which were both higher than that between mercury and sea salt aerosol. This suggests that anthropogenic sources contributed more to wet deposition of mercury than sea salt aerosols, but cannot affect the variation of deposition flux remarkably.

Table 3 shows that the ions most significantly correlated with mercury were formate $(r=0.99)$, calcium $(r=0.93)$, and potassium $(r=0.88)$. Formate is indicative of volatile organic compounds mostly emitted from vegetation (Dordevic et al., 2010). Good correlations were seen between calcium and potassium $(r=0.76)$, as well as calcium and magnesium $(r=0.92)$, which suggested their crustal origin, namely local resuspended soil and dust from inland cities (Guentzel et al., 1998; Shen et al., 2012; Salve et al., 2006). In view of good correlations of mercury with formate, calcium, potassium, and magnesium $(r=0.73)$, natural sources including vegetation and resuspended soil should be considered as an important factor influencing the wet deposition of mercury in Nanjing. As suggested in Zhu et al. (2012), natural sources also could make a significant contribution to the higher monthly average levels of TGM in Nanjing, especially in summer, due to Nanjing and its surrounding areas being one of the largest natural emission regions in summertime China. The re-volatilized mercury from soil and vegetation could be previously deposited anthropogenic mercury.

\subsection{Size-fractionated particulate mercury}

From June 2011 to February 2012, 17 campaigns of particle sampling in eight size stages were conducted at our site. The average total $\mathrm{Hg}^{\mathrm{P}}$ in $\mathrm{PM}_{10}$ during our study period was $1.10 \pm 0.57 \mathrm{ng} \mathrm{m}^{-3}$ with a range of $0.32-2.04 \mathrm{ng} \mathrm{m}^{-3}$. While the level of $\mathrm{Hg}^{\mathrm{P}}$ in Nanjing was much higher than that in rural areas in China (30.7 $\mathrm{pg} \mathrm{m}^{-3}$ for Mt. Gongga (Fu et al., 2008) and $77 \mathrm{pg} \mathrm{m}^{-3}$ for Mt. Changbai (Wan et al., 2009b)), it is very close to that in Beijing $\left(1.18 \pm 0.82 \mathrm{ng} \mathrm{m}^{-3}\right.$ ) (Wang et al., 2006) and comparable to that in other Chinese cities such as Shanghai $\left(0.233-0.529 \mathrm{ng} \mathrm{m}^{-3}\right.$; Xiu et al., 2005) and Changchun (0.022-1.984 $\mathrm{ng} \mathrm{m}^{-3}$; Fang et al., 2001). Compared globally, the $\mathrm{Hg}^{\mathrm{P}}$ concentration in Nanjing was far 
Table 2. Summary of wet deposition of mercury in China and other countries.

\begin{tabular}{llccrll}
\hline Locations & Classification & Period & THg $\left(\mathrm{ng} \mathrm{L}^{-1}\right)$ & Wet deposition & Reference \\
\hline Mt.Gongga, China & Rural & $2005.5-2006.4$ & $9.9 \pm 2.8$ & 9.1 & $\mu \mathrm{g} \mathrm{m}^{-2} \mathrm{yr}^{-1}$ & Fu et al. (2008) \\
Mt.Gongga, China & Rural & $2005.5-2007.4$ & 14.3 & 26.1 & $\mu \mathrm{g} \mathrm{m}^{-2} \mathrm{yr}^{-1}$ & Fu et al. (2010) \\
Wujiang River, China & Rural & 2006 & 36.0 & 34.7 & $\mu \mathrm{g} \mathrm{m}^{-2} \mathrm{yr}^{-1}$ & Guo et al. (2008) \\
Mt. Leigong, China & Rural & $2008.5-2009.5$ & 4.0 & 6.1 & $\mu \mathrm{g} \mathrm{m}^{-2} \mathrm{yr}^{-1}$ & Fu et al. (2010) \\
Mt. Fanjing, China & Rural & 1996 & - & 115 & $\mu \mathrm{g} \mathrm{m}^{-2} \mathrm{yr}^{-1}$ & Xiao et al. (1998) \\
Changchun, China & Urban & $1999.7-2000.7$ & $162-697$ & 152.4 & $\mu \mathrm{g} \mathrm{m}^{-2} \mathrm{yr}^{-1}$ & Fang et al. (2004) \\
Guiyang, China & Urban & $1997-1998$ & - & $43.8 \pm 35.8$ & $\mu \mathrm{g} \mathrm{m}^{-2} \mathrm{month}^{-1}$ & Tan et al. (2000) \\
Nanjing, China & Urban & $2011.6-2012.3$ & 52.9 & $0.7-18.1$ & $\mu \mathrm{g} \mathrm{m}^{-2} \mathrm{month}^{-1}$ & This study \\
Chuncheon, Korea & Rural & $2006.8-2008.7$ & 8.8 & 9.4 & $\mu \mathrm{g} \mathrm{m}^{-2} \mathrm{yr}^{-1}$ & Ahn et al. (2011) \\
Tokyo, Japan & Urban & $2002.12-2003.11$ & 8.7 & 16.7 & $\mu \mathrm{g} \mathrm{m}^{-2} \mathrm{yr}^{-1}$ & Sakata et al. (2005) \\
Aichi, Japan & Urban & $2004.4-2005.3$ & 7.8 & 13.1 & $\mu \mathrm{g} \mathrm{m}^{-2} \mathrm{yr}^{-1}$ & Sakata and Asakura (2007) \\
Hyogo, Japan & Urban & $2004.4-2005.4$ & 9.5 & 14 & $\mu \mathrm{g} \mathrm{m}^{-2} \mathrm{yr}^{-1}$ & Sakata and Asakura (2007) \\
London, UK & Urban & $1999.1-2005.12$ & $43.8-76.0$ & $15.0-45.3$ & $\mu \mathrm{g} \mathrm{m}^{-2} \mathrm{yr}^{-1}$ & Yang et al. (2009) \\
Wisconsin, USA & Urban & $2004.6-2005.5$ & 13.9 & 6.7 & $\mu \mathrm{g} \mathrm{m}^{-2} \mathrm{yr}^{-1}$ & Rutter et al. (2008) \\
Virginia, USA & Rural & $2006.6-2006.9$ & 6.8 & 9 & $\mu \mathrm{g} \mathrm{m}^{-2} \mathrm{yr}^{-1}$ & Kolker et al. (2008) \\
New Hampshire, USA & Rural, Costal & $2006.6-2009.8$ & $0.75-65.09$ & $8.41-12.33$ & $\mu \mathrm{g} \mathrm{m}^{-2} \mathrm{yr}^{-1}$ & Lombard et al. (2011) \\
\hline
\end{tabular}

Table 3. The correlation coefficients between mercury and major ions in rainwater (italics show $p>0.05$ ).

\begin{tabular}{|c|c|c|c|c|c|c|c|c|c|c|c|c|c|}
\hline & $\mathrm{Hg}$ & $\mathrm{H}^{+}$ & $\mathrm{F}^{-}$ & $\mathrm{Cl}^{-}$ & $\mathrm{NO}_{3}^{-}$ & $\mathrm{SO}_{4}^{2-}$ & $\mathrm{Na}^{+}$ & $\mathrm{NH}_{4}^{+}$ & $\mathrm{K}^{+}$ & $\mathrm{Ca}^{2+}$ & $\mathrm{Mg}^{2+}$ & Formate & Oxalate \\
\hline $\mathrm{Hg}$ & 1.00 & 0.65 & 0.78 & 0.23 & 0.44 & 0.39 & 0.37 & 0.52 & 0.88 & 0.93 & 0.73 & 0.99 & 0.33 \\
\hline $\mathrm{H}^{+}$ & & 1.00 & 0.40 & 0.04 & 0.15 & 0.05 & 0.15 & -0.06 & 0.53 & 0.62 & 0.59 & 0.71 & 0.07 \\
\hline $\mathrm{F}^{-}$ & & & 1.00 & 0.75 & 0.87 & 0.87 & 0.82 & 0.82 & 0.94 & 0.75 & 0.81 & 0.96 & 0.89 \\
\hline $\mathrm{Cl}^{-}$ & & & & 1.00 & 0.85 & 0.94 & 0.98 & 0.67 & 0.63 & 0.17 & 0.73 & 0.78 & 0.90 \\
\hline $\mathrm{NO}_{3}^{-}$ & & & & & 1.00 & 0.95 & 0.87 & 0.89 & 0.72 & 0.45 & 0.73 & 0.71 & 0.97 \\
\hline $\mathrm{SO}_{4}^{2-}$ & & & & & & 1.00 & 0.94 & 0.83 & 0.71 & 0.38 & 0.80 & 0.78 & 0.99 \\
\hline $\mathrm{Na}^{+}$ & & & & & & & 1.00 & 0.70 & 0.74 & 0.29 & 0.76 & 0.91 & 0.91 \\
\hline $\mathrm{NH}_{4}^{+}$ & & & & & & & & 1.00 & 0.70 & 0.49 & 0.47 & 0.59 & 0.88 \\
\hline $\mathrm{K}^{+{ }^{+}}$ & & & & & & & & & 1.00 & 0.76 & 0.69 & 0.97 & 0.78 \\
\hline $\mathrm{Ca}^{2+}$ & & & & & & & & & & 1.00 & 0.92 & 0.98 & 0.36 \\
\hline $\mathrm{Mg}^{2+}$ & & & & & & & & & & & 1.00 & 0.89 & 0.78 \\
\hline Formate & & & & & & & & & & & & 1.00 & 0.66 \\
\hline Oxalate & & & & & & & & & & & & & 1.00 \\
\hline
\end{tabular}

higher than that in most cities around the world such as Tokyo $\left(0.098 \pm 0.051 \mathrm{ng} \mathrm{m}^{-3}\right.$; Sakata and Marumoto, 2002), Detroit (0.021 $\pm 0.030 \mathrm{ng} \mathrm{m}^{-3}$; Liu et al., 2007), and Seoul $\left(6.8 \pm 6.5 \mathrm{pg} \mathrm{m}^{-3}\right.$; Kim et al., 2012). There was a clear seasonal cycle of $\mathrm{Hg}^{\mathrm{P}}$ in Nanjing (Fig. 2). The highest monthly averaged concentration was $1.95 \mathrm{ng} \mathrm{m}^{-3}$, measured in December, which was a factor of $>4$ higher than the lowest one in August $\left(0.46 \mathrm{ng} \mathrm{m}^{-3}\right)$. The seasonal average concentration was the highest $\left(1.82 \mathrm{ng} \mathrm{m}^{-3}\right)$ in winter and low in summer $\left(0.70 \mathrm{ng} \mathrm{m}^{-3}\right)$ and fall $\left(0.87 \mathrm{ng} \mathrm{m}^{-3}\right)$. In our site, the average ratio of $\mathrm{Hg}^{\mathrm{P}}$ concentration to TGM measured was up to 0.25 , which was extremely high compared to that at other sites over the world, where it was always lower than 0.1 (Mao and Talbot, 2012; Wan et al., 2009a; Valente et al., 2007), while the ratios in summer ranged between 0.042 and 0.097 . One of the most important reasons for the highest concentration and ratios of $\mathrm{Hg}^{\mathrm{P}}$ to TGM in winter was the increasing concen- tration of $\mathrm{PM}_{10}$. The concentration of $\mathrm{PM}_{10}$ averaged over our sampling period in winter was $103 \mu \mathrm{g} \mathrm{m}^{-3}$, compared to $63 \mu \mathrm{g} \mathrm{m}^{-3}$ in summer and $69 \mu \mathrm{g} \mathrm{m}^{-3}$ in fall. This may be attributed to the fact that particles are scavenged much less efficiently in winter (Mao et al., 2012). In addition, the concentrations of $\mathrm{Hg}^{\mathrm{P}}$ and $\mathrm{PM}_{10}$ showed good correlation, with a correlation coefficient of 0.67 . The concentration of particles appeared to have a large effect on the concentration of $\mathrm{Hg}^{\mathrm{P}}$ in the atmosphere.

Fractional measurements were used to characterize the size distribution of $\mathrm{Hg}^{\mathrm{P}}$ in Nanjing. Figure 3 illustrates the averaged percentages of $\mathrm{Hg}^{\mathrm{P}}$ in each size fraction. More than half of the $\mathrm{Hg}^{\mathrm{P}}$ existed in the particle size of less than $2.1 \mu \mathrm{m}$, which can be regarded as fine particles. In particular, the $\mathrm{Hg}^{\mathrm{P}}$ in the particle size between 0.7 and $2.1 \mu \mathrm{m}$ contributed $39.8 \%$ to the total $\mathrm{Hg}^{\mathrm{P}}$ in $\mathrm{PM}_{10}$. Gas-particle transformation plays a vital role in formation of $\mathrm{Hg}^{\mathrm{P}}$ in fine particles as 


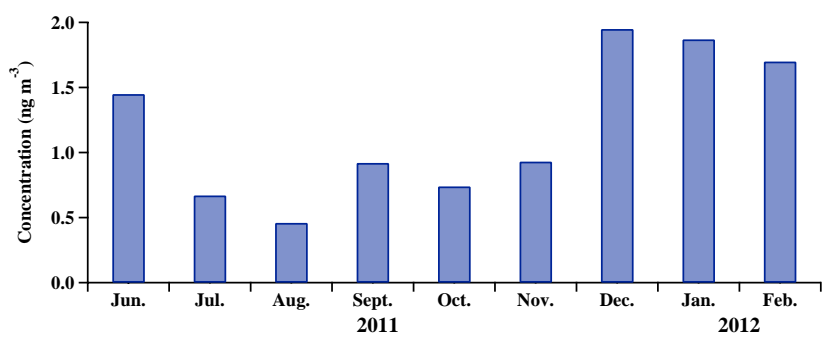

Fig. 2. Monthly variation of $\mathrm{Hg}^{\mathrm{P}}$ concentration during June 2011February 2012.

more than $95 \%$ atmospheric mercury exists in gaseous form (Xiu et al., 2005). The other way to form $\mathrm{Hg}^{\mathrm{P}}$ in fine particles is adsorption of gaseous mercury onto fine particles, which are primarily produced by condensation and coagulation of combustion products (Ames et al., 1997). Also, a lower peak was found in the particle size between 4.7 and $10 \mu \mathrm{m}$, which is regarded as the coarse particle size range. Compared with $\mathrm{Hg}^{\mathrm{P}}$ in fine particles, $\mathrm{Hg}^{\mathrm{P}}$ in coarse particles may form through adsorption of gaseous mercury onto coarse particles commonly generated by natural sources such as salt spray and dust, and mechanical processes from anthropogenic sources (Mamane et al., 2008). Furthermore, quite different size distributions of $\mathrm{Hg}^{\mathrm{P}}$ for seasons are illustrated in Fig. 3. More $\mathrm{Hg}^{\mathrm{P}}$ is concentrated in the three most coarse size fractions $(>4.7 \mu \mathrm{m})$ in summer, with a percentage of $22.7 \%$, while a higher percentage of $\mathrm{Hg}^{\mathrm{P}}$ in fine particles $<2.1 \mu \mathrm{m}$ was measured in fall and winter (59.6 and $53.8 \%$, respectively). A possible reason for this shift in particle size was that gas-particle partitioning of atmospheric mercury actively occurred on fine particles during the cold season (Kim et al., 2012). This was demonstrated by a controlled laboratory system designed by Rutter and Schauer (2007), which suggested that the partition coefficient $K_{\mathrm{P}}$ (Eq. 3) is inversely correlated with temperature.

$K_{\mathrm{p}}=\frac{\mathrm{Hg}^{\mathrm{P}} / \mathrm{PM}}{\mathrm{TGM}}$,

where $\mathrm{Hg}^{\mathrm{P}}$ is the concentration of particulate mercury, PM represents the particle mass, and TGM is the concentration of gaseous mercury.

Moreover, the mass percentage of $\mathrm{Hg}^{\mathrm{P}}$ in the size fraction between 0.7 and $1.1 \mu \mathrm{m}$ in summer and that between 1.1 and $2.1 \mu \mathrm{m}$ in winter were particularly high, accounting for 19.2 and $17.3 \%$ of total $\mathrm{Hg}^{\mathrm{P}}$, respectively. However, the predominant mercury species in these fractions have not been identified. Xiu et al. (2009) suggested that all mercury species including $\mathrm{Hg}^{0}, \mathrm{HgCl}_{2}, \mathrm{HgBr}_{2}, \mathrm{HgSO}_{4}, \mathrm{HgO}, \mathrm{HgS}$, and methylated mercury may deposit onto particles. Data of species are needed to further study the causes for the peaks.

In order to minimize the effect of $\mathrm{PM}_{10}$ concentration, the mercury content in particles $\left(\mathrm{Hg}^{\mathrm{P}} / \mathrm{PM}_{10}\right)$ was studied. Figure 4 shows the seasonal variation of the mercury content in

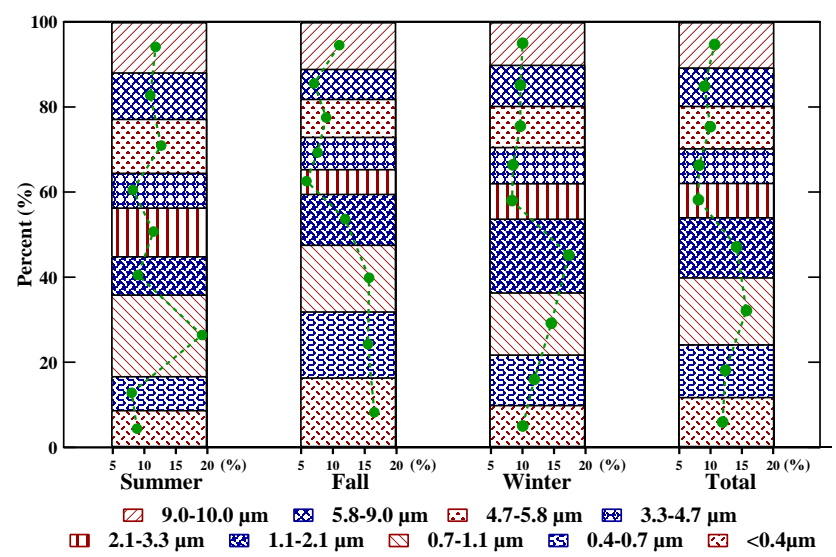

Fig. 3. Size distribution of $\mathrm{Hg}^{\mathrm{P}}$ mass in each season and over the whole study period.

each size fraction. The size distributions of averaged mercury content in particles were bimodal during our study period, with two peaks in the bins of $<0.7 \mu \mathrm{m}$ and $4.7-5.8 \mu \mathrm{m}$. These two peaks were close in magnitude, with content for both higher than $25 \mathrm{ng} \mathrm{mg}^{-1}$, which was unlike the mass distribution. This demonstrated that $\mathrm{Hg}^{\mathrm{P}}$ might have come from two different sources or might have been formed via different mechanisms. Since fine particles possess the most surface area per unit mass, the mercury species with low volatility are preferentially adsorbed onto fine particles (Kim et al., 2012). As a result, the lowest mercury content was measured in the two largest size fractions $(5.8-10.0 \mu \mathrm{m})$. However, the mercury content peak in $4.7-5.8 \mu \mathrm{m}$ needs to be studied further. In addition, mercury content in summer in the four finest size fractions below $2.1 \mu \mathrm{m}$ was $17-53 \%$ lower than that in fall and winter. A possible explanation was that higher temperatures in summer caused detachment of the volatile mercury that had been adsorbed onto the particles (Xiu et al., 2005). By contrast, the mercury content in coarse particles in summer was comparable with that in fall and winter. Xie et al. (2008) found that GEM was a significant contributor to $\mathrm{Hg}^{\mathrm{P}}$ in large particles. As measured by Zhu et al. (2012), the concentration of TGM was extremely high during summer in Nanjing. More TGM in summer might account for part of the mercury content in coarse particles.

\subsection{Dry deposition of particulate mercury}

Besides wet deposition, dry deposition was the other primary way to scavenge mercury from the atmosphere and deposit it into terrestrial and aquatic ecosystems. The dry deposition flux of $\mathrm{Hg}^{\mathrm{P}}$ was calculated using the ambient concentration of $\mathrm{Hg}^{\mathrm{P}}$ and the size-dependent dry deposition velocity. The concentration of $\mathrm{Hg}^{\mathrm{P}}$ was estimated using measurements of $\mathrm{PM}_{10}$ at our site during the study period. We assumed that the size distribution of $\mathrm{Hg}^{\mathrm{P}}$ and mercury content in $\mathrm{PM}_{10}$ 


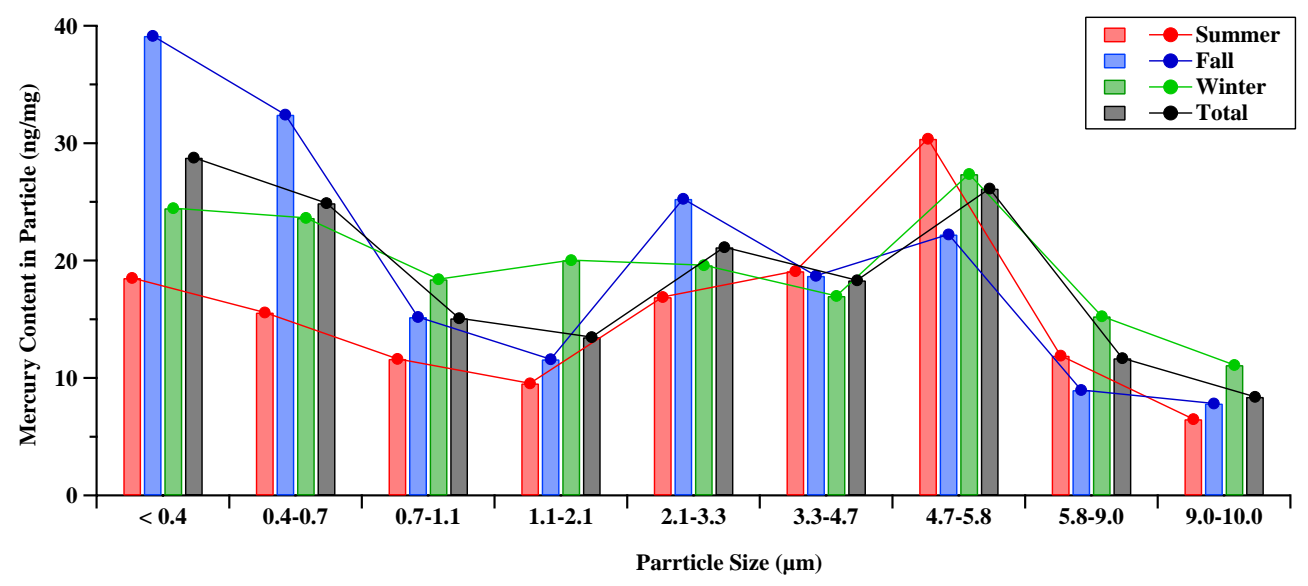

Fig. 4. Mercury content in size-fractionated particles in each season and over the whole study period.

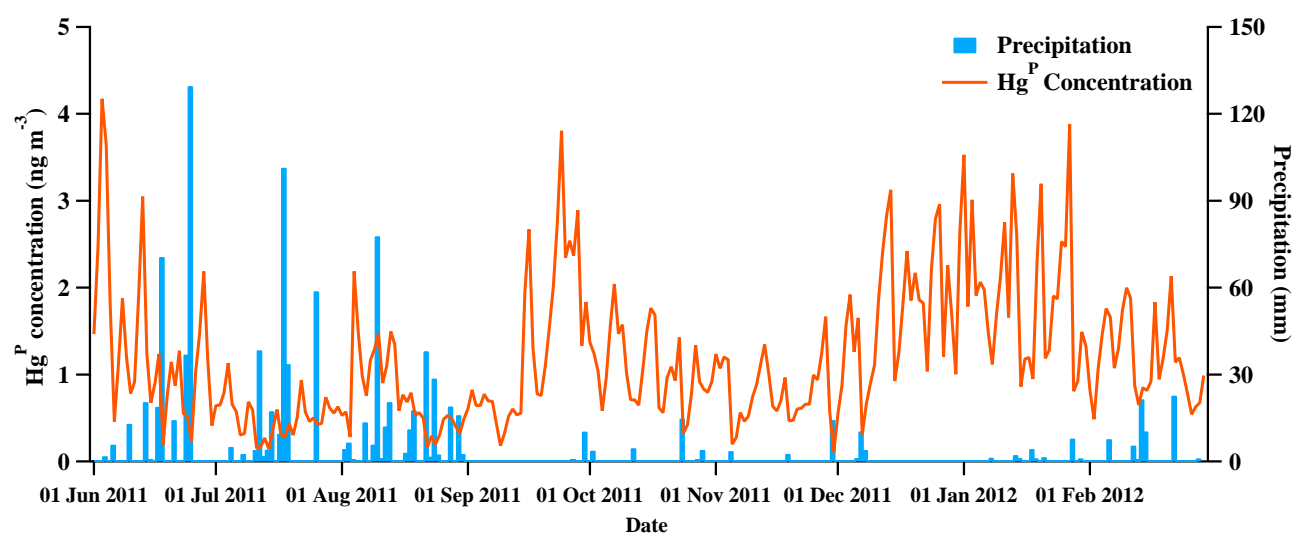

Fig. 5. $\mathrm{Hg}^{\mathrm{P}}$ concentration and precipitation during the study period.

remained constant during the time period following the sample collection time window.

Dry deposition of $\mathrm{Hg}^{\mathrm{P}}$ per unit area was calculated to be $47.2 \mu \mathrm{g} \mathrm{m}^{-2}$ during the 9 months of our study period. Estimated $\mathrm{Hg}^{\mathrm{P}}$ dry deposition was $16.5 \%$ less than the measured mercury wet deposition $\left(56.5 \mu \mathrm{g} \mathrm{m}^{-2}\right)$. Table 4 shows that the lowest seasonal dry deposition flux was in summer, while fluxes in fall and winter were a little higher. But the seasonal variation of dry deposition flux was not as apparent as that of the wet deposition flux. The seasonal variabilities in mercury wet deposition and $\mathrm{Hg}^{\mathrm{P}}$ dry deposition were opposite in phase. The ratios of mercury wet deposition to $\mathrm{Hg}^{\mathrm{P}}$ dry deposition ranged from 0.19 in the fall to 3.89 in the summer. The large precipitation amount as well as mercury wet deposition and the lowest $\mathrm{Hg}^{\mathrm{P}}$ dry deposition in summer possibly reflected the effect of scavenging by precipitation, indicated by every precipitation event followed by decreased $\mathrm{Hg}^{\mathrm{P}}$ concentration at our site (Fig. 5). During precipitation events, the $\mathrm{Hg}^{\mathrm{P}}$ concentration decreased by $56 \%$ on average, ranging from 16 to $94 \%$. Negative correlation between the precipitation amount and $\mathrm{Hg}^{\mathrm{P}}$ concentration was statistically significant, with $r=-0.25$. $\mathrm{Hg}^{\mathrm{P}}$ can be scavenged by rainfall from atmosphere directly, evidenced in lower concentrations of $\mathrm{Hg}^{\mathrm{P}}$ during a precipitation event. In addition, precipitation causes higher humidity and the soil is not as easily resuspended, and thus the $\mathrm{Hg}^{\mathrm{P}}$ bound to wind-blown soil material decreases (Fang et al., 2001b). Furthermore, the relative contribution of $\mathrm{Hg}^{\mathrm{P}}$ in different size fractions to the total dry deposition was calculated. Although the mass percentage of $\mathrm{Hg}^{\mathrm{P}}$ in coarse particles was much less than $\mathrm{Hg}^{\mathrm{P}}$ in fine particles, $\mathrm{Hg}^{\mathrm{P}}$ in coarse particles $(>5.8 \mu \mathrm{m})$ contributed $24.6 \%$ more than $\mathrm{Hg}^{\mathrm{P}}$ in fine particles $(<2.1 \mu \mathrm{m})$ to the total dry deposition due to the extremely high deposition velocity. The dry deposition velocity of particles increased with particle size, so dry deposition of $\mathrm{Hg}^{\mathrm{P}}$ in sizes between 9.0 and $10.0 \mu \mathrm{m}$ occupied more than $30 \%$ of the total for all seasons. The finest $\mathrm{Hg}^{\mathrm{P}}$ contributed around $10 \%$ owing to higher concentrations.

\section{Summary}

A measurement study of wet and dry deposition of sizefractionated particulate mercury was conducted from June 
Table 4. Dry deposition fluxes $\left(\mu \mathrm{g} \mathrm{m}^{-2}\right)$ in each size fraction and in each season.

\begin{tabular}{lrr|rr|rr|rr}
\hline \multirow{2}{*}{ Size $(\mu \mathrm{m})$} & \multicolumn{2}{c}{ Summer } & \multicolumn{2}{c|}{ Fall } & \multicolumn{2}{c|}{ Winter } & \multicolumn{2}{c}{ All data } \\
& Flux & Percent & Flux & Percent & Flux & Percent & Flux & Percent \\
\hline$<0.4$ & 1.0 & $8.1 \%$ & 2.7 & $17.3 \%$ & 1.9 & $9.8 \%$ & 5.6 & $11.8 \%$ \\
$0.4-0.7$ & 0.4 & $3.2 \%$ & 1.1 & $6.9 \%$ & 1.1 & $5.5 \%$ & 2.5 & $5.3 \%$ \\
$0.7-1.1$ & 0.9 & $7.5 \%$ & 0.8 & $5.5 \%$ & 1.0 & $5.2 \%$ & 2.8 & $5.9 \%$ \\
$1.1-2.1$ & 0.4 & $3.1 \%$ & 0.6 & $4.0 \%$ & 1.2 & $6.0 \%$ & 2.2 & $4.6 \%$ \\
$2.1-3.3$ & 0.7 & $6.0 \%$ & 0.4 & $2.6 \%$ & 0.7 & $3.6 \%$ & 1.8 & $3.9 \%$ \\
$3.3-4.7$ & 0.7 & $5.6 \%$ & 0.8 & $4.9 \%$ & 1.2 & $5.9 \%$ & 2.6 & $5.5 \%$ \\
$4.7-5.8$ & 1.5 & $12.6 \%$ & 1.4 & $9.4 \%$ & 2.1 & $10.8 \%$ & 5.1 & $10.8 \%$ \\
$5.8-9.0$ & 2.4 & $20.1 \%$ & 2.2 & $14.5 \%$ & 4.0 & $20.1 \%$ & 8.6 & $18.3 \%$ \\
$9.0-10.0$ & 4.1 & $34.0 \%$ & 5.4 & $35.0 \%$ & 6.5 & $33.1 \%$ & 16.0 & $33.9 \%$ \\
\hline Total & 12.0 & & 15.4 & & 19.8 & & 47.2 & \\
\hline
\end{tabular}

2011 to February 2012 to characterize mercury deposition and $\mathrm{Hg}^{\mathrm{P}}$ in urban Nanjing, China. The VWM concentration of $\mathrm{THg}$ of all rainwater samples was $52.9 \mathrm{ng} \mathrm{L}^{-1}$ during the study period. The mercury wet deposition per unit area was $56.5 \mu \mathrm{g} \mathrm{m}^{-2}$ over 9 months. Seasonal variation was strongly linked to precipitation amount based on a strong correlation $(r=0.99)$ between precipitation and deposition flux. In comparison, wet deposition in urban Nanjing was lower than that in Chinese cities, but much higher than annual deposition in urban areas in North America and Japan. The anthropogenic influence on mercury wet deposition was evidenced by the association between wet deposition of mercury, sulfates, and nitrates. The ions that correlated with mercury in rainwater most significantly were formate, calcium, and potassium, which suggested the importance of natural sources including vegetation and resuspended soil to mercury wet deposition in Nanjing.

Atmospheric particles were sampled in nine size fractions during the study period at our site. The average $\mathrm{Hg}^{\mathrm{P}}$ concentration in $\mathrm{PM}_{10}$ was $1.10 \pm 0.57 \mathrm{ng} \mathrm{m}^{-3}$, comparable to that in other Chinese cities but far higher than that in rural areas in China as well as most cities around the world. A distinct seasonal cycle in $\mathrm{Hg}^{\mathrm{P}}$ concentrations was found with much higher levels in winter than in summer and fall due to increased concentrations of $\mathrm{PM}_{10}$ in winter. More than half of the total $\mathrm{Hg}^{\mathrm{P}}$ existed in particle sizes $<2.1 \mu \mathrm{m}$ and the size distributions of averaged mercury content in particles were bimodal with two peaks at $<0.7 \mu \mathrm{m}$ and $4.7-5.8 \mu \mathrm{m}$. Furthermore, a higher percentage of $\mathrm{Hg}^{\mathrm{P}}$ in coarse particles was measured in summer, while more $\mathrm{Hg}^{\mathrm{P}}$ was concentrated in fine particles occurring in fall and winter. Dry deposition per unit area of $\mathrm{Hg}^{\mathrm{P}}$ was calculated to be $47.2 \mu \mathrm{g} \mathrm{m}^{-2}$, a little less than mercury wet deposition. $\mathrm{Hg}^{\mathrm{P}}$ in coarse particles contributed more to the total dry deposition than $\mathrm{Hg}^{\mathrm{P}}$ in fine particles due to its high deposition velocity. A significant negative correlation between precipitation and $\mathrm{Hg}^{\mathrm{P}}$ concentration reflected the effect of $\mathrm{Hg}^{\mathrm{P}}$ scavenging by rain.
Acknowledgements. The authors would like to thank all members at the AERC (Atmospheric Environment Research Center) of Nanjing University for maintaining instruments and express their sincere appreciation to B. Zhu and $\mathrm{H}$. Wang, who helped to analyze ions in rainfall. This work was supported by the National Key Basic Research Development Program of China (2011CB403406, 2010CB428503), the National Special Fund for the Weather Industry (GYHY201206011), the Specialized Research Fund for the Doctoral Program of Higher Education of China (20110091110010), and the Scientific Research Foundation of Graduate School of Nanjing University (2012CL09), as well as a project funded by the Priority Academic Program Development of Jiangsu Higher Education Institutions (PAPD).

Edited by: C. Barbante

\section{References}

Ahn, M., Yi, S., Holsen, T. M., and Han, Y.: Mercury wet deposition in rural Korea, concentrations and fluxes, J. Environ. Monitor., 13, 2748-2754, 2011.

Ames, M., Gullu, G., and Olmez, I.: Atmospheric mercury in the vapor phase, and in fine and coarse particulate matter at Perch River, New York, Atmos. Environ., 32, 865-872, 1997.

Caffrey, J. M., Landing, W. M., Nolek, S. D., Gosnell, K. J., Bagui, S. S., and Bagui, S. C.: Atmospheric deposition of mercury and major ions to the Pensacola (Florida) watershed: spatial, seasonal, and inter-annual variability, Atmos. Chem. Phys., 10, 5425-5434, doi:10.5194/acp-10-5425-2010, 2010.

Chand, D., Jaffe, D., Prestbo, E., Sartzendruber, P. C., Hafner, W., Weiss-Penzias, P., Kato, S., Takami, A., Hatakeyama, S., and Kajii, Y.: Reactive and particulate mercury in the Asian marine boundary layer, Atmos. Environ., 42, 7988-7996, 2008.

Choi, H., Sharac, T., and Holsen, T.: Mercury deposition in the Adirondacks: A comparison between precipitation and throughfall, Atmos. Environ., 42, 1818-1827, 2008.

Dordevic, D. S., Tosic, I., Unkasevic, M., and Duraskovic, P.: Watersoluble main ions in precipitation over the southeastern Adriatic region; chemical composition and long-range transport, Environ. Sci. Pollut. R., 17, 1591-1598, 2010. 
Ebinghaus, R. , Jennings, S. G., Schroeder, W. H., Berg, T., Donaghy, T., Guentzel, J., Kenny, C. Kock, H. H., Kvietkus, K., Landing, W., Muhleck, T., Munthe, J., Prestbo, E. M., Schneeberger, D., Slemr, F., Sommar, J., Urba, A., Wallschlager, D., and Xiao, Z: International field intercomparison measurements of atmospheric mercury species at Mace Head, Ireland, Atmos. Environ., 33, 3063-3073, 1999.

Fang, F., Wang, Q., and Li, J.: Atmospheric particulate mercury concentration and its dry deposition flux in Changchun City, China, Sci. Total Environ., 281, 229-236, 2001a.

Fang, F., Wang, Q., Liu, R., Ma, Z., and Hao, Q.: Atmospheric particulate mercury in Changchun City, China, Atmos. Environ., 35, 4265-4272, 2001b.

Fang, F., Wang, Q., and Li, J.: Urban environmental mercury in Changchun, a metropolitan city in Northeastern China, source, cycle, and fate, Sci. Total Environ., 330, 159-170, 2004.

Fang, G., Lo, C., Huang, W., Wu, Y., and Huang, J.: Atmosphericparticulates-bound mercury $\mathrm{Hg}(\mathrm{p})$ study at five characteristic sampling sites in Taiwan, Environ. Monit. Assess., 181, 273-289, 2011a.

Fang, G., Lo, C., Chen, J., Wu, Y., Huang, W., and Liu, C.: Application of Dry Deposition Models to Estimate Ambient Air Particulate and Particulate-Bound Mercury $\mathrm{Hg}(\mathrm{p})$ Dry Deposition, Environ. Eng. Sci., 28, 63-70, 2011 b.

Fang, G., Lo, C., Huang, J., Liu, C., and Huang, Y.: Atmospheric Particle Bound Mercury $\mathrm{Hg}(\mathrm{p})$ Concentrations and Amounts in Total Suspended Particulates and Dry Deposition at an Industrial and Wetland Sampling Sites in Taiwan, Environ. Forensics, 12, 200-205, 2011c.

Fang, G., Zhang, L., and Huang, C.: Measurements of sizefractionated concentration and bulk dry deposition of atmospheric particulate bound mercury, Atmos. Environ., 61, 371377, 2012.

Feddersen, D. M., Talbot, R., Mao, H., and Sive, B. C.: Size distribution of particulate mercury in marine and coastal atmospheres, Atmos. Chem. Phys., 12, 10899-10909, doi:10.5194/acp-1210899-2012, 2012.

Feng, X., Sommar, J., Lindqvist, O., and Hong, Y.: Occurrence, Emissions and Deposition of Mercury during Coal Combustion in the Province Guizhou, China, Water, Air Soil Poll., 139, 311324, 2002

Fu, X., Feng, X., Zhu, W., Zheng, W., Wang, S., and Lu, J. Y.: Total particulate and reactive gaseous mercury in ambient air on the eastern slope of the Mt. Gongga area, China, Appl. Geochem., 23, 408-418, 2008.

Fu, X. W., Feng, X., Dong, Z. Q., Yin, R. S., Wang, J. X., Yang, Z. R., and Zhang, H.: Atmospheric gaseous elemental mercury (GEM) concentrations and mercury depositions at a high-altitude mountain peak in south China, Atmos. Chem. Phys., 10, 24252437, doi:10.5194/acp-10-2425-2010, 2010a.

Fu, X., Feng, X., Zhu, W., Rothenberg, S., Yao, H., and Zhang, H.: Elevated atmospheric deposition and dynamics of mercury in a remote upland forest of southwestern China, Environ. Pollut., 158, 2324-2333, 2010b.

Guentzel, J. L., Landing, W. M., Gill, G. A., and Pollman, C. D.: Mercury and major ion in rainfall, throughfall, and foliage from the Florida Everglades, Sci. Total Environ., 213, 43-51, 1998.

Guo, Y., Feng, X., Li, Z., He, T., Yan, H., Meng, B., Zhang, J., and Qiu, G.: Distribution and wet deposition fluxes of total and methyl mercury in Wujiang River Basin, Guizhou, China, Atmos. Environ., 42, 7096-7103, 2008.

Hall, B. D., Manolopoulos, H., Hurley, J. P., Schauer, J. J., StLouis, V. L., Kenski, D., Graydon, J., Babiarz, C. L., Cleckner, L. B., and Keeler, G. J.: Methyl and total mercury in precipitation in the Great Lakes region, Atmos. Environ., 39, 7557-7569, 2005.

Keeler, G., Glinsorn, G., and Pirrone, N.: particulate mercury in the atmosphere: its significance,transport, transformation and sources, Water Air Soil Pollut., 80, 159-168, 1995.

Keeler, G. J., Gratz, L. E., and Al-Wali, K.: Long-term Atmospheric Mercury Wet Deposition at Underhill, Vermont, Ecotoxicology, 14, 71-83, 2005.

Kim, P., Han, Y., Holsen, T., and Yi, S.: Atmospheric particulate mercury: Concentrations and size distributions, Atmos. Environ., 61, 94-102, 2012.

Kolker, A., Engle, M. A., Orem, W. H., Bunnell, J. E., Lerch, H. E., Krabbenhoft, D. P., Olson, M. L., and McCord, J. D.: Mercury, trace elements and organic constituents in atmospheric fine particulate matter, Shenandoah National Park, Virginia, USA: A combined approach to sampling and analysis, Geostand. Geoanal. Res., 32, 279-293, 2008.

Lai, S. O., Holsen, T. M., Hopke, P. K., and Liu, P.: Wet deposition of mercury at a New York state rural site: Concentrations, fluxes, and source areas, Atmos. Environ., 41, 4337-4348, 2007.

Landis, M. S. and Keeler, G. J.: Atmospheric mercury deposition to Lake Michigan during the Lake Michigan mass balance study, Environ. Sci. Technol., 36, 4518-4524, 2002.

Landis, M. S., Vette, A. F., and Keeler, G. J.: Atmospheric mercury in the Lake Michigan basin: influence of the Chicago/Gary urban area, Environ. Sci. Technol., 36, 4508-4517, 2002.

Lestari, P., Oskouie, A. K., and Noll, K. E.: Size distribution and dry deposition of particulate mass, sulfate and nitrate in an urban area, Atmos. Environ., 37, 2507-2516, 2003.

Lindberg, S. E., Hanson, P. J., Meyers, T. P., and Kim, K. H.: Air/surface exchange of mercury vapor over forests - the need for a reassessment of continental biogenic emissions, Atmos. Environ., 32, 895-908, 1998.

Lindqvist, O.: Mercury in the Swedish environment: recent research on causes, consequences and corrective methods, Water Air Soil Pollut., 55, 1-261, 1991.

Liu, B., Keeler, G. J., Dvonch, J. T., Barres, J. A., Lynam, M. M., Marsik, F. J., and Morgan, J. T.: Temporal variability of mercury speciation in urban air, Atmos. Environ., 41, 1911-1923, 2007.

Lombard, M. A. S., Bryce, J. G., Mao, H., and Talbot, R.: Mercury deposition in Southern New Hampshire, 2006-2009, Atmos. Chem. Phys., 11, 7657-7668, doi:10.5194/acp-11-76572011, 2011.

Lu, J. and Schroeder, W. H.: Annual time-series of total filterable atmospheric mercury concentrations in the Arctic, Tellus B, 56, 213-222, 2004.

Mamane, Y., Perrino Cinzia, Y. O., and Catrmbone, M.: Source characterization of fine and coarse particles at the East Mediterranean coast, Atmos. Environ., 42, 6114-6130, 2008.

Mao, H. and Talbot, R.: Speciated mercury at marine, coastal, and inland sites in New England - Part 1: Temporal variability, Atmos. Chem. Phys., 12, 5099-5112, doi:10.5194/acp-12-50992012, 2012.

Mao, H., Talbot, R., Hegarty, J., and Koermer, J.: Speciated mercury at marine, coastal, and inland sites in New England - Part 
2: Relationships with atmospheric physical parameters, Atmos. Chem. Phys., 12, 4181-4206, doi:10.5194/acp-12-4181-2012, 2012.

Mason, R. P., Lawson, N. M., and Sheu, G. R.: Annual and seasonal trends in mercury deposition in Maryland, Atmos. Environ., 34, 1691-1701, 2000.

Miller, E., Vanarsdale, A., Keeler, G., Chalmers, A., Poissant, L., Kamman, N., and Brulotte, R.: Estimation and mapping of wet and dry mercury deposition across northeastern North America, Ecotoxicology, 14, 53-70, 2005.

Munthe, J., Hultberg, H., and Iverfeldt, A.: Mechanisms of deposition of methylmercury and mercury to coniferous forests, Water Air Soil Pollut., 80, 363-371, 1995.

National Atmospheric Deposition Program: 2011 Annual Summary, Mercury Deposition Network, 18-19, http://nadp.sws. uiuc.edu/lib/data/2011as.pdf (last access: 3 March 2014), 2012.

Peters, K. W. and Eiden, R.: Modeling the dry deposition velocity of aerosol particles to a spruce forest, Atmos. Environ., 21, 15611571, 1992.

Prestbo, E. M. and Gay, D. A.: Wet deposition of mercury in the U.S. and Canada, 1996-2005: Results and analysis of the NADP mercury deposition network (MDN), Atmos. Environ., 25, 42234233, 2009.

Rea, A. W., Keeler, G. J., and Scherbatskoy, T.: The deposition of mercury in throughfall and litterfall in the Lake Champlain watershed. a short-term study, Atmos. Environ., 30, 3257-3263, 1996.

Rolfhus, K. R., Sakamoto, H. E., Cleckner, L. B., Stoor, R. W., Babiarz, C. L., Back, R. C., Manolopoulos, H., and Hurley, J. P.: Distribution and fluxes of total and methyl mercury in Lake Superior, Environ. Sci. Technol., 37, 865-872, 2003.

Rutter, A. P. and Schauer, J. J.: The effect of temperature on the gasparticle partitioning of reactive mercury in atmospheric aerosols, Atmos. Environ., 41, 8647-8657, 2007.

Rutter, A. P., Schauer, J. J., Lough, G. C., Snyder, D. C., Kolb, C. J., Klooster, S. V., Rudolf, T., Manolopoulos, H., and Olson, M. L.: A comparison of speciated atmospheric mercury at an urban center and an upwind rural location, J. Environ. Monitor., 10, 102-108, 2008.

Sakata, M. and Asakura, K.: Estimating contribution of precipitation scavenging of atmospheric particulate mercury to mercury wet deposition in Japan, Atmos. Environ., 41, 1669-1680, 2007.

Sakata, M. and Marumoto, K.: Formation of atmospheric particulate mercury in the Tokyo metropolitan area, Atmos. Environ., 36, 239-246, 2002.

Sakata, M. and Marumoto, K.: Wet and dry deposition fluxes of mercury in Japan, Atmos. Environ., 39, 3139-3146, 2005.

Salve, P. R., Maurya, A., Sinha, R., Gawane, A. G., and Wate, S. R.: Characterization and Source Identification of Major Inorganic Ions in Precipitation of Nagpur, India, B. Environ. Contam. Tox., 77, 305-311, 2006.

Sanei H., Outridge, P. M., Goodarzi, F., Armstrong, D., Warren, K., and Fishback, L.: Wet deposition mercury fluxes in the Canadian sub-Arctic and southern Alberta, measured using an automated precipitation collector adapted to cold regions, Atmos. Environ., 44, 1672-1681, 2010.

Schroeder, W. H. and Munthe, J.: Atmospheric mercury - an overview, Atmos. Environ., 32, 809-822, 1998.
Seinfeld, J. H. and Pandis, S. N.: Atmospheric Chemistry and Physics, 2nd Edn., Wiley, New York, p. 384, 2006.

Selvendiran, P., Driscoll, C. T., Montesdeoca, M. R., and Bushey, J. T.: Inputs, storage, and transport of total methyl mercury in two temperate forest wetlands, J. Geophys. Res., 113, G00C01, doi:10.1029/2008JG000739, 2008.

Shen, Z., Zhang, L., Cao, J., Tian, J., Liu, L., Wang, G., Zhao, Z., Wang, X., Zhang, R., and Liu, S.: Chemical composition, sources, and deposition fluxes of water-soluble inorganic ions obtained from precipitation chemistry measurements collected at an urban site in northwest China, J. Environ. Monitor., 14, 30003008, 2012.

Slinn, W. G. N.: Predictions for particle deposition to vegetative surface, Atmos. Environ., 16, 1785-1794, 1982.

Streets, D. G., Hao, J. M., Jiang, J. K., Chan, M., Tian, H. Z., and Feng, X. B.: Anthropogenic mercury emissions in China, Atmos. Environ., 39, 7789-7806, 2005.

Tan, H., He, J. L., Liang, L., Lazoff, S., Sommer, J., Xiao, Z. F., and Lindqvist, O.: Atmospheric mercury deposition in Guizhou, China, Sci. Total Environ., 259, 223-230, 2000.

US EPA: Method 1631: Revision E, Mercury in water by Oxidation, Purge and Trap, and Cold Vapor atomic Fluorescence Spectrometry, United States Environmental Protection Agency, 1-33, 2002.

Valente, R. J., Shea, C., Humes, K. L., and Tanner, R. L.: Atmospheric mercury in the Great Smoky Mountains compared to regional and global levels, Atmos. Environ., 41, 1861-1873, 2007.

Vanarsdale, A., Weiss, J., Keeler, G., Miller, E., Boulet, G., Brulotte, R., and Poissant, L.: Patterns of mercury deposition and concentration in northeastern North America (1996-2002), Ecotoxicology, 14, 37-52, 2005.

Wan, Q., Feng, X. B., Lu, J. L., Zheng, W., Song, X. J., Li, P., Han, S. J., and $\mathrm{Xu}, \mathrm{H} .:$ Atmospheric mercury in Changbai Mountain area, northeastern China I: the season distribution pattern of total gaseous mercury and its potential sources, Environ. Res. 109, 201-206, 2009a.

Wan, Q., Feng, X. B., Lu, J. L., Zheng, W., Song, X. J., Li, P., Han, S. J., and $\mathrm{Xu}, \mathrm{H}$.: Atmospheric mercury in Changbai Mountain area, northeastern China II: The distribution of reactive gaseous mercury and particulate mercury and mercury deposition fluxes, Environ. Res., 109, 721-727, 2009b.

Wang, Z., Zhang, X., Chen, Z., and Zhang, Y.: Mercury concentrations in size-fractionated airborne particles at urban and suburban sites in Beijing, China, Atmos. Environ., 40, 2194-2201, 2006.

Wangberg, I., Munthe, J., Berg, T., Ebinghaus, R., Kock, H. H., Temme, C., Bieber, E., Spain, T. G., and Stolk, A.: Trends in air concentration and deposition of mercury in the coastal environment of the North Sea Area, Atmos. Environ., 41, 2612-2619, 2007.

Wu, Y., Wang, S., Streets, D. G., Hao, J., Chan, M., and Jiang, J.: Trends in anthropogenic mercury emissions in China from 1995 to 2003, Environ. Sci. Technol., 40, 5312-5318, 2006.

Xiao, Z., Sommar, J., Lindqvist, O., Tan, H., and He, J.: Atmospheric mercury deposition on Fanjing Mountain Nature Reserve, Guizhou, China, Chemosphere, 36, 2191-2200, 1998.

Xiu, G., Cail, J., Zhang, D., Bueler, A., Lee, S., Shen, Y., Xu, L., Huang, X., and Zhang, P.: Characterization of size fractioned particulate mercury in Shanghai ambient air, Atmos. Environ., 39, 419-427, 2005. 
Xiu, G., Cail, J., Zhang, W., Zhang, D., Bueler, A., Lee, S., Shen, Y., Xu, L., Hunag, X., and Zhang, P.: Speciated mercury in sizefractionated particles in Shanghai ambient air, Atmos. Environ., 43, 3145-3154, 2009.

Yang, H., Berry, A., Rose, N., and Berg, T.: Decline in atmospheric mercury deposition in London, J. Environ. Monitor., 11, 15181522, 2009.

Zhang, L., Gong, S., Padro, J., and Barrie, L. A.: A size-segregated particle dry deposition scheme for an atmospheric aerosol module, Atmos. Environ., 35, 549-560, 2001.
Zhang, L. M., Wright, L. P., and Blanchard, P.: A review of current knowledge concerning dry deposition of atmospheric mercury, Atmos. Environ., 43, 5853-5864, 2009.

Zhu, J., Wang, T., Talbot, R., Mao, H., Hall, C. B., Yang, X., Fu, C., Zhuang, B., Li, S., Han, Y., and Huang, X.: Characteristics of atmospheric Total Gaseous Mercury (TGM) observed in urban Nanjing, China, Atmos. Chem. Phys., 12, 12103-12118, doi:10.5194/acp-12-12103-2012, 2012. 